\title{
Rancang Bangun Sistem Pembersih Otomatis Pada Solar Panel Menggunakan Wiper Berbasis Mikrokontroler
}

\author{
Muhamad Rizal Wira Kusumaa ${ }^{1}$ Esa Apriakar ${ }^{2}$, Djuniadi ${ }^{3}$ \\ 1,2,3Jurusan Teknik Elektro, \\ Fakultas Teknik, \\ Universitas Negeri Semarang, Semarang \\ ${ }^{1}$ mrwirakusuma@gmail.com, ${ }^{2}$ esa.apriaskar@mail.unnes.ac.id, ${ }^{3}$ djuniadi@mail.unnes.ac.id
}

\begin{abstract}
Abstrak
Penelitian ini memiliki tujuan untuk memudahkan pekerjaan manusia dalam masalah pembersihan solar panel. Apabila sekitar solar panel terdapat debu dan kotoran, alat pembersih ini akan otomatis membersihkan solar panel. Selain berdasarkan kadar debu, alat ini juga akan beroperasi ketika waktu menunjukan pukul 06.00 WIB dan 18.00 WIB. Metode yang digunakan dalam rancang bangun ini diawali dengan pembuatan prototype pembersih otomatis solar panel, membuat sistem kendali intensitas debu dan waktu untuk kebutuhan alat pembersih otomatis solar panel. Proses pembacaan menggunakan sensor debu dan modul RTC, untuk penggerak wiper menggunakan motor servo. Sebagai pengendalinya menggunakan arduino uno dengan pemrograman bahasa C. Hasil dari pengambilan data menunjukan bahwa alat ini efisien dalam pembersihan solar panel, karena terdapat selisih tegangan rata rata sekitar $44,6 \%$ dalam pengujian waktu dan $73 \%$ dalam pengujian berdasarkan kadar debu.
\end{abstract}

Kata kunci: Arduino uno, pembersih solar panel, wiper, sensor debu, modul RTC

\begin{abstract}
This study aims to assist human in dealing with solar panel cleaning problem. If there are any dusts and dirts on the panel, the proposed mechanism will cleanse the panel automatically. Beside that, it will be functioning during 06.00 a.m to 18.00 p.m. The methods started with making the prototype, followed by developing dust intensity controlling systems, and setting the appropriate time interval. The input data are originated from dust sensors and RTC, while the wiper driver uses servomotor. The main controller used is Arduino uno, programmed in $C$ language. The result shows that the device works efficiently, as there occur average of voltage difference of $44.6 \%$ in time testing, and $73 \%$ in dust testing.
\end{abstract}

Keywords: Arduino uno, solar panel cleaner, wiper, dust sensor, RTC module

\section{Pendahuluan}

Pemanfaatan energi telah berkembang dan meningkat sesuai dengan perkembangan manusia itu sendiri [1]. Energi matahari merupakan salah satu yang dimanfaatkan, khususnya untuk solar panel. Solar panel dapat mengubah energi matahari menjadi energi listrik [2]-[3]. Semakin besar cahaya yang mengenai permukaan solar panel, maka energi listrik yang didapat akan semakin besar [4]. Solar panel sebagai sumber energi listrik alternatif dapat dimanfaatkan oleh masyarakat yang memerlukan energi listrik [5]. Penggunaan energi listrik tersebut biasanya digunakan untuk rumah, gedung, 
penerangan jalan umum dan lainnya [6]. Penggunaan energi matahari adalah upaya saat ini untuk mengurangi emisi karbon global yang telah menjadi isu lingkungan, sosial, dan ekonomi global utama dalam beberapa tahun terakhir [7]. Faktor-faktor yang dapat mempengaruhi kinerja solar panel adalah penempatan solar panel yang menimbulkan penimbunan debu, kotoran burung dan noda air (garam) [8]. Hal itu dapat secara signifikan menurunkan efisiensi solar panel. Efisiensi modul solar panel berkurang sebesar $10-25 \%$ karena kerugian pada inverter, kabel, dan pengotoran modul (debu dan serpihan) [9].

Tujuan utama alat ini adalah menyediakan mekanisme pembersihan debu otomatis untuk solar panel. Sistem pembersihan yang tradisional masih dilakukan secara manual. Pembersihan manual memiliki beberapa kerugian seperti kerusakan panel, risiko kecelakaan pekerja, kesulitan pergerakan karena terbatasnya ruangan maupun jarak, pemeliharaan yang buruk, dan lainnya. Alat ini dirancang untuk mengatasi kesulitan yang timbul pada pembersih solar panel yang masih tradisional dan tidak efektif [10]. Dari penelitian [11] menjelaskan tentang pembersih debu panel surya secara otomatis, yang cara kerjanya dengan melakukan pengoperasian alat sebanyak dua kali dalam sehari, yaitu pada pagi hari dan siang hari. Alat tersebut sudah diprogram menggunakan Digital Programmable Timer, yang berfungsi untuk mengontrol sistem waktu secara otomatis dari hari senin sampai hari minggu. Adapun modul relay 4 channel berfungsi untuk menggerakkan driver motor sebagai sliding roda untuk menggerakan motor pembersih (kemoceng). Modul HC-05 Serial Bluetooth berfungsi mengkoneksikan dari arduino uno ke media gadget android untuk mengoperasikan sistem secara manual [11]. Dalam hal ini tidak dapat membersihkan debu maupun kotoran yang menempel kuat pada permukaaan solar panel.

Penelitian yang dilakukan [12] menjelaskan pembersih solar panel menggunakan aktuator piezoelektrik. Aktuator piezoelektrik yang bergerak secara linear digunakan untuk menggerakkan wiper yang terpasang pada aktuator. Tekanan antara wiper, solar panel dan aktuator mendorong wiper untuk menyapu lapisan debu di permukaan panel surya [12]. Peneliti lain [13] melakukan penelitian tentang solar brush yang merupakan sistem pembersihan robot untuk panel SPV. Robot 'solar brush' beroperasi di atas solar panel. Robot Ini nirkabel dan daya dapat diisi ulang. Memiliki sikat pembersih yang menyapu debu dan beratnya hanya 2,5 kg [13]. Penelitian lainnya [14] menjelaskan tentang sistem pembersih secara otomatis dengan mencuci dan membilas panel surya, yang terdiri dari reservoir untuk konsentrat sabun. Ada juga filter sedimen yang mengandung softener. Sistem tersebut juga memiliki katup anti-siphon, untuk mencegah backwashing ke dalam sistem. Sistem terdiri dari pengontrol yang secara otomatis melakukan siklus cuci dan bilas. Pemrograman pengontrol dapat diubah sesuai kebutuhan [14].

Melihat dari beberapa penelitian [12] dengan menggunakan wiper dan penelitian dari [14] dengan sistem pembersih yang mencuci solar panel, maka tercetus ide untuk membuat rancang bangun alat ini yang menggunakan wiper sebagai pembersihnya dan penyemprotan air ke permukaan solar panel sebagai pencuci awalnya. Rancangan teknologi yang dibuat dalam penelitian ini bekerja berdasarkan sensor debu dan pengaturan waktu yang telah ditetapkan saat pagi dan sore hari. Dari pembersih otomatis ini diharapkan dapat meningkatkan efisiensi dalam pembersihan solar panel. Rancangan ini bekerja berdasarkan sistem elektronik yang dikendalikan berdasarkan perintah dari mikrokontroler arduino uno yang dilengkapi dengan sensor debu GP2Y1010AU0F dan real time clock (RTC) DS3231. 


\section{Metodologi Penelitian}

Dalam penelitian ini menggunakan metode rancang bangun alat, yang diawali dengan pembuatan prototype pembersih otomatis. Membuat sistem kendali intensitas debu dan pengaturan waktu menggunakan modul RTC, yang disesuaikan dengan kebutuhan dari proses pembersihan otomatis pada solar panel.

\subsection{Waktu dan Tempat}

Penelitian ini dimulai pada bulan Agustus 2019 sampai November 2019, dengan menggunakan tempat di rumah penulis dan laboratorium elektro, Universitas Negeri Semarang.

\subsection{Metode Pengumpulan Data}

Dalam mengumpulkan data penelitian, penulis menggunakan metode yaitu:

a. Studi Pustaka

Penulis mencari dan mempelajari berbagai referensi yang berkaitan dengan pembersih otomatis solar panel, sensitifitas sensor debu dan aplikasi modul real time clock. Dan mencari artikel jurnal nasional maupun internasional

b. Studi Eksperimen

Penulis melakukan secara langsung pembuatan pembersih otomatis solar panel menggunakan wiper berbasis mikrokontroler, yang menggunakan sensor debu dan modul RTC. Serta dalam pengambilan datanya.

\subsection{Perancangan Penelitian}

Instrumen dan komponen elektronika yang dibutuhkan terdiri atas :
1. Arduino uno
7. Kabel Jumper
2. Modul RTC DS3231
8. Power Supply $9 \mathrm{Vdc}$
3. Sensor Debu GP2Y1010AU0F
9. Pompa Air dc
4. Motor Servo MG996R
10. Relay 2-Channel
5. Solar Panel $12 \mathrm{Vdc}$
11. Kapasitor $220 \mu \mathrm{F}$
6. Resistor $150 \mathrm{Ohm}$
12. Wiper

Spesifikasi alat yang akan digunakan untuk membuat rancang bangun alat pembersih otomatis solar panel adalah sebagai berikut :

1. Menggunakan Arduino uno ATmega328P sebagai pengendali.

2. Menggunakan sensor debu GP2Y1010AU0F sebagai perangkat yang mendeteksi intensitas debu udara.

3. Modul RTC DS3231 sebagai perangkat yang menunjukan waktu yang akurat.

4. Motor servo MG996R sebagai penggerak wiper dengan spesifikasi : tegangan kerja $5,8-7,2 \mathrm{Vdc}$, torsi $10 \mathrm{~kg} / \mathrm{cm}$, berat $55 \mathrm{~g}$.

5. Pompa air dc sebagai komponen yang akan mendorong air dan menumpahkan ke permukaan solar panel.

6. Relay 2 Channel sebagai switch yang dikontrol oleh arduino uno

7. Satu set pembersih solar panel yang meliputi :

a. Wiper yang dibuat dari rangka berbahan melamin dan busa padat sebagai penyapunya. 
b. Solar panel $12 \mathrm{Vdc}$.

c. Rangka sebagai tempat panel surya, yang dibuat menggunakan kayu dan kardus 3 layer sebagai dindingnya.

d. Tempat motor servo dan tempat sensor debu.

\subsection{Perancangan Desain}

Desain alat merupakan desain secara keseluruhan yang dibuat dengan tujuan supaya mudah dalam melakukan pembuatan dan pengujian alat. Desain alat tersebut bisa dilihat pada Gambar 1.

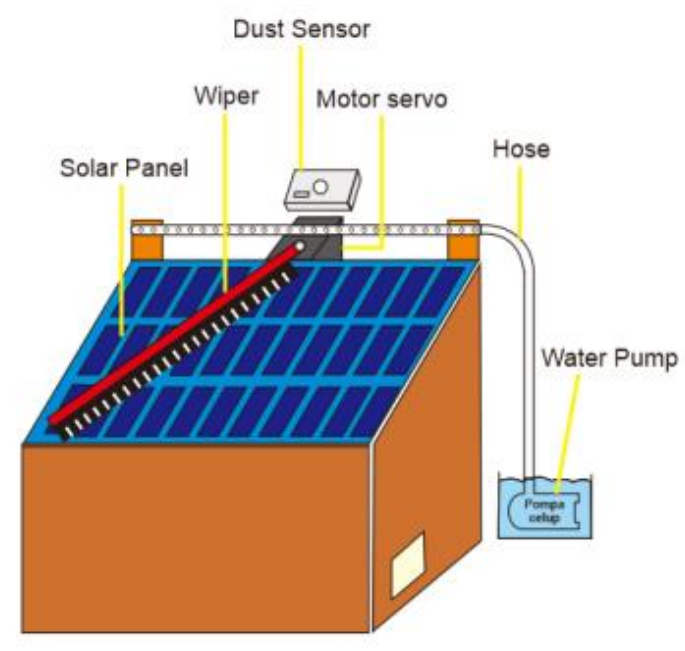

Gambar 1. Desain alat

Desain alat ini menggunakan rangka dari bahan kayu dan sebagai dindingnya menggunakan bahan dari kardus 3 layer. Di bagian permukaan atau letak solar panel dibuat miring, dengan tujuan agar saat air mengalir di permukaan solar panel air langsung jatuh ke depan. Wiper menggunakan rangka dari bahan melamin, untuk penyapu airnya menggunakan bahan busa padat.

Servo diletakan dibagian atas solar panel dan diletakkan ditengah karena akan bergerak secara $180^{\circ}$. Sensor debu dipasang pada atas motor servo menghadap depan dan diposisikan miring, yang bertujuan dapat membaca kondisi debu di sekitar solar panel. Pompa air dimasukkan pada tempat penampungan air karena pompa ini berjenis pompa celup, pompa akan mendorong air ke pipa dan akan dikeluarkan saat berada di atas tepatnya di atas permukaan solar panel melalui lubang-lubang kecil.

\subsection{Skema Rangkaian Alat}

Desain elektronik rancang bangun alat ini menggunakan mikrokontroler Arduino uno dengan ATmega328P sebagai pengendalinya. Mikrokontroler tersebut memiliki 14 port input maupun output digital dan juga 6 port input maupun output analog. Perancangan hardware ini terdari dari perancangan rangkaian modul RTC DS3231 yang menghubungkan port GND ke port GND arduino sebagai ground, VCC ke port VCC arduino sebagai sumber tegangan, SDA ke port SDA arduino dan SCL ke port SCL arduino sebagai data. 


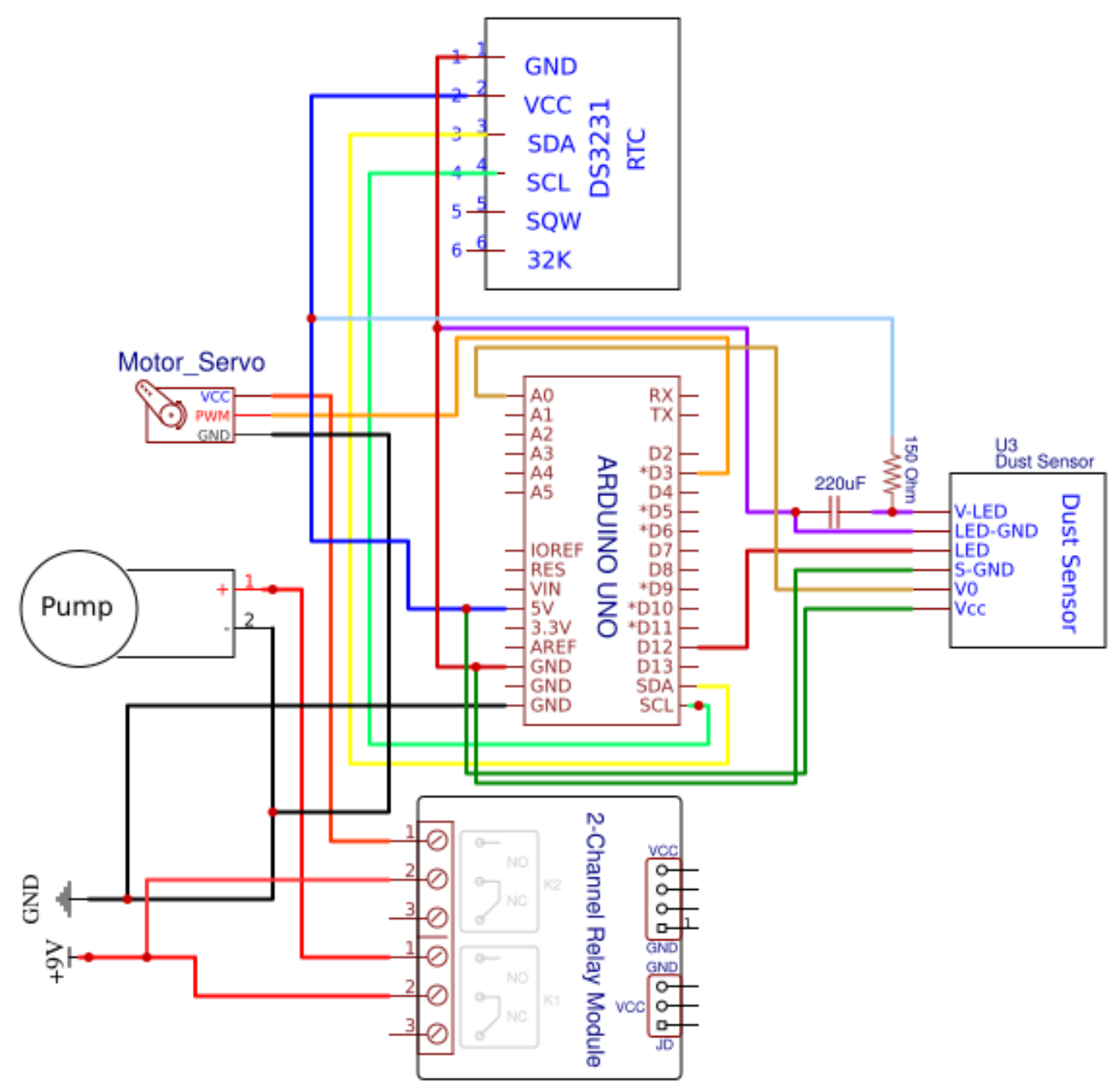

Gambar 2. Skema rangkaian alat

Adapun untuk perancangan rangkaian sensor debu, port V-LED sebagai sumber tegangan untuk LED dihubungkan ke tegangan sumber setelah melalui rangkaian low pass filter (LPF). Rangkaian filter tersebut dibentuk dengan resistor $150 \mathrm{Ohm}$ dan kapasitor $220 \mathrm{uF}$ untuk meloloskan sinyal dengan frekuensi rendah. Port LED-GND digunakan sebagai port ground untuk LED, sedangkan port LED ke port digital (D12) arduino. S-GND berfungsi sebagai ground, V0 sebagai data analog hasil pembacaan sensor yang masuk ke port A0 arduino, dan VCC sebagai sumber tegangan utama yang masuk ke port VCC arduino.

Perancangan rangkaian 2 channel relay pada perangkat yang dibuat menggunakan relay jenis NO (Normally Open). Relay ini digunakan sebagai switch aktuator saat alat beroperasi. Penambahan rangkaian pompa yang menggunakan sumber tegangan DC dimaksudkan untuk menyiramkan air di permukaan panel surya. Untuk menggerakkan wiper, digunakan rangkaian servo yang dihubungkan ke serial port digital 3 (D3) arduino sebagai data, VCC ke port VCC arduino sebagai sumber tegangan, dan GND ke port GND arduino sebagai ground. Sebagai ilustrasi, rangkaian elektronik yang digunakan pada penelitian ini dapat dilihat pada Gambar 2. Penambahan power supply 9 Vdc digunakan untuk memberi tegangan tambahan guna mengoperasikan aktuator. Hal ini dikarenakan output maksimal dari arduino hanya 5 VDC. 


\subsection{Blok Diagram Sistem}

Dari blok diagram pada Gambar 3, dapat diketahui bahwa masukan untuk kontroller (Arduino UNO) adalah kondisi kadar debu $>0,04 \mathrm{mg} / \mathrm{m}^{3}$, kemudian kontroller akan menyalakan pompa terlebih dahulu selama 10 detik dan diberi jeda 5 detik, selanjutnya servo menyala menggerakan wiper dengan sudut pergerakan $180^{\circ}$.

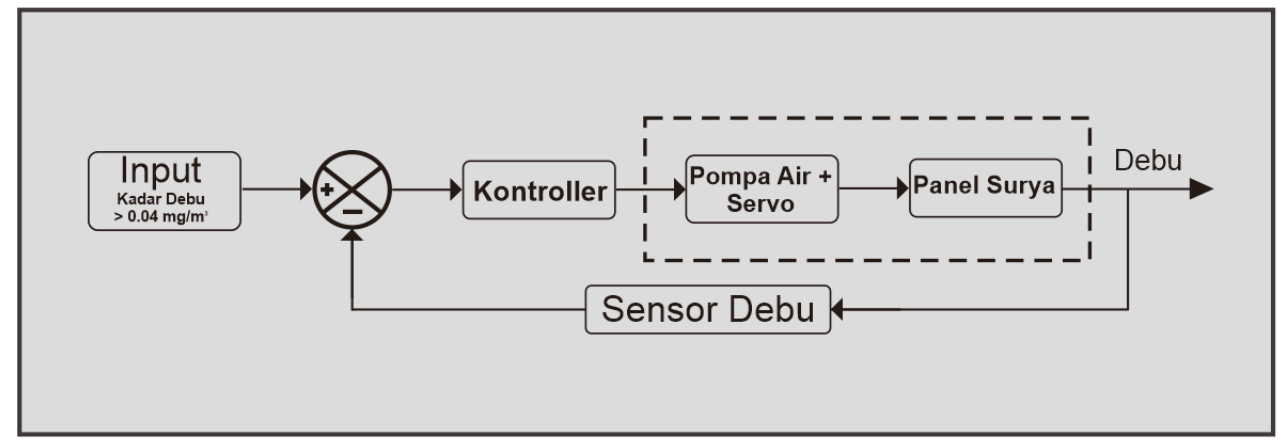

Gambar 3. Diagram blok sistem

Sistem kendali ini terdapat umpan balik (feedback), berupa sensor debu yang akan membandingkan kadar debu saat ini dengan kadar debu referensi. Sehingga sistem kendali ini dapat disebut juga dengan sistem kendali loop tertutup (closed loop).

\subsection{Perancangan Software}

Perancangan software dilakukan untuk memudahkan dalam pengoperasian alat nantinya [15]. Yang perlu diperhatikan dalam hal ini adalah langkah dalam pembuatan rancangan program, yang bisa dilihat pada Gambar 4 .

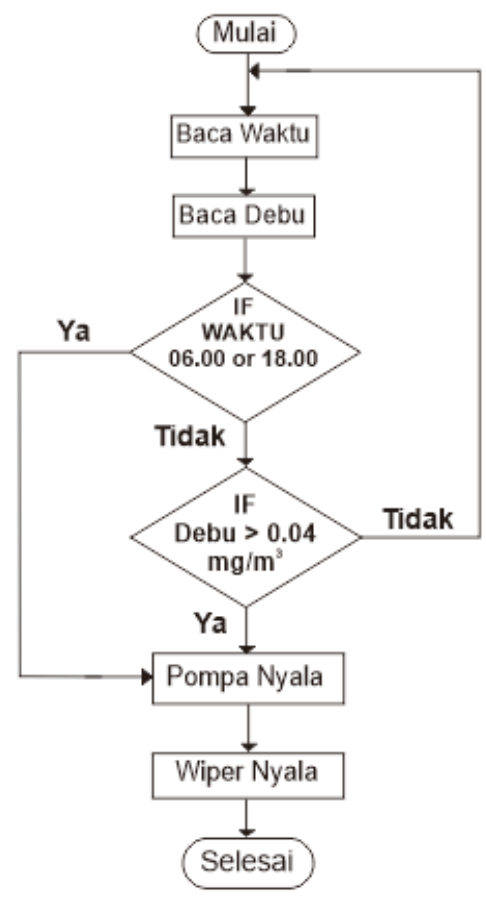

Gambar 4. Flowchart alur kerja alat 
Diagram di atas merupakan diagram alir prinsip kerja alat pembersih otomatis solar panel. Dari diagram di atas dapat dijelaskan bahwa sebelum seluruh komponen dirangkai menjadi satu, perlu melakukan uji coba pada sensor debu terhadap kadar debu di lingkungan luar. Hal ini diperlukan untuk melihat sensitivitas dari sensor.

Sistem di atas menggunakan sistem kendali closed loop. Dimulai dari modul RTC membaca waktu dan sensor debu membaca kadar debu, selanjutnya masuk pada fungsi logika di mana jika waktu menunjukan waktu 06.00 WIB atau 18.00 WIB alat akan bekerja dengan pompa menyala, lalu secara bergantian wiper menyala, jika tidak akan masuk ke fungsi logika kedua yaitu jika kadar debu $>0,04 \mathrm{mg} / \mathrm{m}^{3}$ alat akan bekerja dengan pompa menyala, lalu secara bergantian wiper meyala, jika tidak sistem akan kembali membaca waktu dan kadar debu.

\section{Hasil dan Pembahasan}

Bagian utama dari sistem ini adalah pertama untuk menyalakan pompa air, yang mana pompa akan mengaliri permukaan solar panel melalui pipa $8 \mathrm{~mm}$. Yang kedua untuk menggerakkan wiper, yang difungsikan untuk membersihkan permukaan solar panel. Sistem wiper ini berjalan secara bergantian dengan pengaliran air yang selalu pertama beroperasi lalu wiper akan beroperasi. Wiper akan bergerak secara $180^{\circ}$ secara bolak balik. Wiper yang digunakan terbuat dari rangka berbahan melamin dan sebagai penyapunya adalah busa padat yang fleksibel. Sedangkan yang menggerakkan wiper secara $180^{\circ}$ tersebut adalah motor servo MG996R.

Penggunaan servo ini karena memiliki kekuatan torsi yang besar yaitu 9,4 kg. Sistem Wiper ini dikontrol berdasarkan perintah program yang telah di input ke mikrokontroler arduino uno. Perintah tersebut mulai dari pengaktifan sistem elektrikal, pembacaan waktu oleh modul real time clock (RTC) dan pembacaan sensor debu. Jika berdasarkan waktu alat ini di set akan bekerja saat pukul 18.00 WIB dan 06.00 WIB. Diharapkan solar panel sebelum dan sesudah digunakan sudah dalam keadaan bersih. Jika berdasarkan sensor debu, sistem wiper akan beroperasi jika debu di sekitar solar panel melebihi nilai referensi yaitu $0,04 \mathrm{mg} / \mathrm{m}^{3}$. Prototype yang sudah dibuat dapat dilihat pada Gambar 5 .
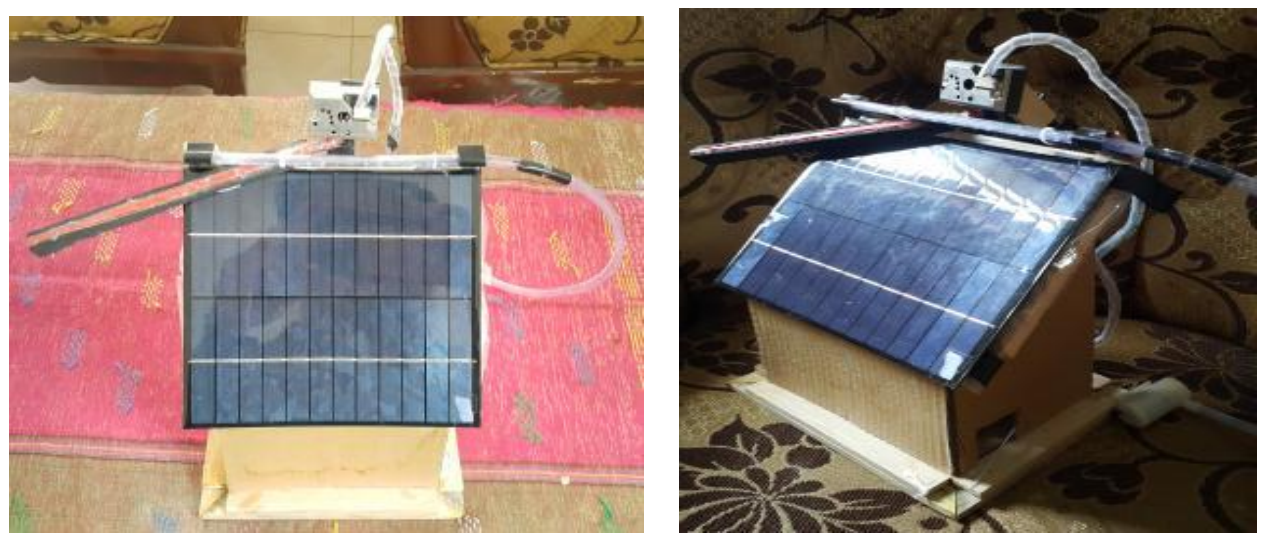

Gambar 5. Prototype alat

Berdasarkan dari hasil pengujian yang dilakukan, maka diperolehlah data yang akan menjadi perbandingan antara tegangan sebelum dibersihkan dan tegangan sesudah dibersihkan. Data tersebut adalah: 
- Pengujian berdasarkan waktu

Pengujian alat pembersih otomatis solar panel berdasarkan waktu dilakukan pada hari Minggu 1 Desember 2019 hingga hari Selasa 3 Desember 2019. Pengujian dilakukan di waktu pagi dan sore hari. Hasil pengujian tersebut tertera pada Tabel 1.

Tabel 1. Pengujian alat berdasarkan waktu

\begin{tabular}{|c|c|c|c|c|}
\hline \multirow{2}{*}{ Hari } & Waktu & $\begin{array}{c}\text { Tegangan Sebelum } \\
\text { Dibersihkan }\end{array}$ & $\begin{array}{c}\text { Tegangan Sesudah } \\
\text { dibersihkan }\end{array}$ & Selisih \\
\hline \multirow{3}{*}{ Minggu } & Pagi & $10,77 \mathrm{~V}$ & $11,2 \mathrm{~V}$ & $0,43 \mathrm{~V}$ \\
\cline { 2 - 5 } & Sore & $9,6 \mathrm{~V}$ & $9,7 \mathrm{~V}$ & $0,1 \mathrm{~V}$ \\
\hline \multirow{2}{*}{ Senin } & Pagi & $13,32 \mathrm{~V}$ & $13,41 \mathrm{~V}$ & $0,9 \mathrm{~V}$ \\
\cline { 2 - 5 } & Sore & $5,60 \mathrm{~V}$ & $5,64 \mathrm{~V}$ & $0,04 \mathrm{~V}$ \\
\hline \multirow{3}{*}{ Selas } & Pagi & $12,38 \mathrm{~V}$ & $13,39 \mathrm{~V}$ & $1,01 \mathrm{~V}$ \\
\cline { 2 - 5 } & Sore & $8,19 \mathrm{~V}$ & $8,39 \mathrm{~V}$ & $0,20 \mathrm{~V}$ \\
\hline
\end{tabular}

Dari data pengujian tersebut, dapat dilihat bahwa tegangan solar panel sebelum dan sesudah dibersihkan selalu menunjukan selisih tegangan. Selisih rata-rata tersebut sekitar $44,6 \%$. Saat pagi hari terlihat selisih yang cukup tinggi, ini dikarenakan saat pengujian di pagi hari cahaya matahari dalam kondisi yang baik. Sedangkan saat sore hari selisih tegangan terlihat lebih kecil dari selisih tegangan pada pagi hari karena cahaya matahari saat pengujian dalam kondisi tidak maksimal karena mendekati matahari tenggelam.

\section{- Pengujian berdasarkan Kadar Debu}

Pengujian alat pembersih otomatis solar panel berdasarkan kadar debu ditunjukkan pada Tabel 2.

Tabel 2. Pengujian alat berdasarkan kadar debu

\begin{tabular}{|c|c|c|c|c|}
\hline Intensitas & Kadar Debu & $\begin{array}{c}\text { Tegangan Sebelum } \\
\text { Dibersihkan }\end{array}$ & $\begin{array}{c}\text { Tegangan Sesudah } \\
\text { dibersihkan }\end{array}$ & Selisih \\
\hline Rendah & $0,04 \mathrm{mg} / \mathrm{m}^{3}$ & $8,92 \mathrm{~V}$ & $9,09 \mathrm{~V}$ & $0,17 \mathrm{~V}$ \\
\hline Sedang & $0,17 \mathrm{mg} / \mathrm{m}^{3}$ & $13,01 \mathrm{~V}$ & $13,56 \mathrm{~V}$ & $0,55 \mathrm{~V}$ \\
\hline Tinggi & $0,30 \mathrm{mg} / \mathrm{m}^{3}$ & $12,03 \mathrm{~V}$ & $13,51 \mathrm{~V}$ & $1,48 \mathrm{~V}$ \\
\hline
\end{tabular}

\section{RENDAH :}

Dalam intensitas rendah ini kadar debu yang terdeteksi oleh sensor debu adalah 0,04 $\mathrm{mg} / \mathrm{m} 3$. Pada kondisi ini permukaan solar panel terdapat debu atau kotoran yang sedikit, yakni berupa partikel-partikel halus dan kecil. Intensitas ini tidak terlalu berpengaruh pada perubahan tegangan solar panel, yang mana selisih tegangan sebelum dan sesudah dibersihkan hanya $0,17 \mathrm{~V}$.

SEDANG :

Dalam intensitas sedang ini kadar debu terdeteksi oleh sensor debu adalah 0,17 mg/m3. Pada kondisi ini permukaan solar panel diselimuti oleh debu atau kotoran yang relative lebih banyak dibandingkan dengan saat kondisi rendah. Partikel-partikel kotoran atau debunya lebih terlihat jika dibanding dengan intensitas rendah. Pada intensitas ini 
pembersihan solar panel cukup berpengaruh terhadap perubahan tegangan solar panel. Selisih tegangan sebelum dan sesudah dibersihkan adalah 0,55 V.

\section{TINGGI :}

Dalam intensitas tinggi ini kadar debu terdeteksi oleh sensor debu adalah 0,30 mg/m3. Kondisi ini mencerminkan permukaan solar panel yang terdapat debu atau kotoran sangat banyak. Partikel-partikel kotoran atau debu yang menutupi solar panel sangat terlihat jika dibanding dengan intensitas sedang. Pada intensitas ini, perubahan tegangan solar panel sebelum dan sesudah dibersihkan jauh lebih signifikan, yakni sebesar 1,48 V.

\section{Kesimpulan dan Saran}

Setelah dilakukan serangkaian pengujian dan analisa. Dapat disimpulkan bahwa alat pembersih otomatis solar panel menggunakan wiper berbasis mikrokontroler telah dibuat untuk memaksimalkan dalam penyerapan energi matahari oleh panel surya. Alat ini berfungsi dengan baik, secara sistem mekanik maupun secara sistem elektrikal. Pada hasil data pengujian selalu menunjukan selisih tegangan sebelum dibersihkan maupun sesudah dibersihkan, berdasarkan waktu maupun kadar debu udara pada panel surya. Pada pagi hari menunjukan selisih tegangan yang tinggi, dikarenakan kondisi matahari yang baik. Sedangkan saat sore hari, menunjukan selisih tegangan yang relatif kecil, karena kondisi cahaya matahari yang tidak maksimal. Dari hasil tersebut menunjukan bahwa alat ini efisien dalam pembersihan panel surya, karena terdapat selisih tegangan rata rata sekitar $44,6 \%$ dalam pengujian waktu dan $73 \%$ dalam pengujian berdasarkan kadar debu. Saran dari hasil penelitian ini adalah masih adanya hal yang harus dikembangkan lebih lanjut. Salah satu contohnya adalah pemberian pelindung atau pengaman pada bagian sistem elektrikal, karena komponen-komponen alat ini terletak di luar dan tidak tahan terhadap air.

\section{Daftar Pustaka}

[1] T. A. Djoko Adi Widodo, Suryono, "Pemberdayaan Energi Matahari Sebagai Energi Listrik Lampu Pengatur Lalu Lintas," J. Tek. Elektro, vol. 2, no. 2, hal. 133-138, 2010.

[2] M. Abrori, S. Sugiyanto, dan T. F. Niyartama, “Pemanfaatan Solar Cell Sebagai Sumber Energi Alternatif dan Media Pembelajaran Praktikum Siswa Di Pondok Pesantren 'Nurul Iman' Sorogenen Timbulharjo, Sewon, Bantul, Yogyakarta Menuju Pondok Mandiri Energi," J. Bakti Saintek J. Pengabdi. Masy. Bid. Sains dan Teknol., vol. 1, no. 1, hal. 17, 2017.

[3] M. Rif'an, S. H. Pramono, M. Shidiq, R. Yuwono, H. Suyono, dan F. Suhartati, "Optimasi Pemanfaatan Energi Listrik Tenaga Matahari Di Jurusan Teknik Elektro Universitas Brawijaya," J. EECCIS, vol. 6, no. 1, hal. 44-48, 2012.

[4] Y. Wiranatha, J. Kusuma, N. Soedjarwanto, A. Trisanto, dan D. Despa, “Rancang Bangun Penggerak Otomatis Panel Surya Menggunakan Sensor Photodioda Berbasis Mikrokontroller Atmega 16," J. Rekayasa dan Teknol. Elektro, vol. 9, no. 1, hal. 11-20, 2015.

[5] B. H. Purwoto, Jatmiko, M. A. F., dan I. F. Huda, “Efisiensi Penggunaan Panel Surya sebagai Sumber Energi Alternatif," Emitor, vol. 18, no. 1, hal. 10-42, 2017.

[6] A. Gaur dan G. N. Tiwari, "Performance of Photovoltaic Modules of Different Solar 
Cells," J. Sol. Energy, vol. 2013, hal. 1-13, 2013.

[7] E. Kabir, P. Kumar, S. Kumar, A. A. Adelodun, dan K. H. Kim, "Solar energy: Potential and future prospects," Renew. Sustain. Energy Rev., vol. 82, hal. 894-900, September 2018.

[8] A. Gheitasi, A. Almaliky, dan N. Albaqawi, "Development of An Automatic Cleaning System for Photovoltaic Plants," in IEEE PES Asia-Pacific Power and Energy Engineering Conference (APPEEC), hal. 1-4, 2015.

[9] M. Mani dan R. Pillai, "Impact of Dust on Solar Photovoltaic (PV) Performance: Research Status, Challenges and Recommendations," Renew. Sustain. Energy Rev., vol. 14, no. 9, hal. 3124-3131, 2010.

[10]M. B, A. Bari, dan P. C M, “B, M., Bari, A., \& C M, P, "Automatic Solar Panel Cleaning System," Int. J. Adv. Sci. Res. Eng., vol. 4, no. 7, hal. 26-31, 2018.

[11]D. B. Wibowo, E. Prasetyo; D. Natosudjono, Fiddiansyah, "Rancang Bangun Alat Pembersih Debu Panel Surya (Solar Cell) Secara Otomatis," Progr. Stud. Tek. Elektro, Fak. Tek. Pakuan 1, vol. 1, no. 1, hal. 1-11, 2018.

[12]X. Lu, Q. Zhang, dan J. Hu, "A Linear Piezoelectric Actuator Based Solar Panel Cleaning System," Energy, vol. 60, no. 41, hal. 401-406, Okt 2013.

[13]A. Sayyah, M. N. Horenstein, dan M. K. Mazumder, "Energy Yield Loss Caused by Dust Deposition on Photovoltaic Panels," Sol. Energy, vol. 107, hal. 576-604, September 2014.

[14]A. K. Mondal dan K. Bansal, "A Brief History and Future Aspects in Automatic Cleaning Systems for Solar Photovoltaic Panels," Adv. Robot., vol. 29, no. 8, hal. 515524, Apr 2015.

[15]A. D. Darusman, M. Dahlan, dan F. S. Hilyana, "Rancang Bangun Prototype Alat Penjemur Pakaian Otomatis Berbasis Arduino Uno," Simetris J. Tek. Mesin, Elektro dan Ilmu Komput., vol. 9, no. 1, hal. 513-518, 2018. 